\title{
Postać Maryi w kontekście statusu żydowskich kobiet w Palestynie I wieku
}

W ostatnich dziesięcioleciach w teologii biblijnej coraz bardziej wzrasta zainteresowanie żydowskimi korzeniami chrześcijaństwa. Zaczęło się od tzw. third quest, czyli trzeciego etapu po-

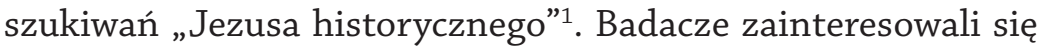
wówczas postacią Jezusa w kontekście judaizmu biblijnego i żydowskich zwyczajów religijnych. Równocześnie coraz bardziej rozwijał się nurt badań zwanych parting of the ways, analizują-

1 Do ważnych prac w tym obszarze należy zaliczyć: S. Ben-Chorin, Jesus in Judentum, Wuppertal 1970; E.P. Sanders, Jesus and Judaism, Philadelphia 1985; H. Falk, Jesus the Farisee: A New Look at the Jewishness of Jesus, New York 1985; P. Fredriksen, From Jesus to Christ: The Origins of the New Testament Image of Jesus, Yale 1988; G. Vermes, The Religion of Jesus the Jew, London 1993; J.P. Meier, A Marginal Jew. Rethinking a Historical Jesus, II: Mentor, Message, and Miracles, New York-London-Toronto-Sydney-Auckland 1994; J.D. Crossan, Historyczny Jezus. Kim byt i czego nauczat, tłum. M. Stopa, Warszawa 1997; J. Charlesworth, Gesù nel giudaismo del suo tempo alla luce delle più recenti scoperte, tłum. D. Tomasetto, Torino 1998²; R. Bartnicki, Ewangelie synoptyczne. Geneza i interpretacja, Warszawa 2003; S. Ben-Chorin, Bruder Jesus. Der Nazarener in juedischer Sicht, Guetersloh 2005; J.H. Charlesworth, The Historical Jesus. An Essential Guide, Nashville 2008; A. Le Donne, The Historiographical Jesus. Memory, Typology, and the Son of David, Waco 2009; tenże, Historical Jesus. What Can We Know and How We Know It?, Grand Rapids 2011. 
cych proces rozchodzenia się Kościoła i Synagogi². Proces ten doprowadził do wyłonienia się z judaizmu biblijnego, skoncentrowanego wokół świątyni jerozolimskiej, dwóch odrębnych religii: judaizmu rabinicznego i chrześcijaństwa. Na razie jednak powstało niewiele prac poświęconych odkrywaniu żydowskiej tożsamości Maryi ${ }^{3}$.

W ukazywaniu Maryi jako Żydówki z Galilei w Palestynie konieczne staje się zarysowanie kontekstu społecznego i religijnego, w jakim przyszło żyć kobietom - wyznawczyniom judaizmu w tamtym czasie. I takie jest też założenie niniejszej prezentacji.

2 Ważne dzieła w tym obszarze to: J. Parkes, The Conflict of the Church and the Synagogue, New York 1934; A. Cohen, The Parting of the Ways: Judaism and the Rise of Christianity, London 1954; R. Murray, The Parting of the Ways, CJR 20 (1987), s. 42-44; R. Bauckham, The Parting of the Ways. What Happened and Why, ST 47 (1993), s. 135-151; V. Martin, A House Divided. The Parting of the Ways Between Synagogue and Church, New York 1995; The Ways That Never Parted. Jews and Christians in Late Antiquity and the Early Middle Ages, red. A.H. Becker, A.Y. Reed, Text and Studies in the Ancient Judaism 95, Tübingen 2003; J. Dunn, The Partings of the Ways: Between Christianity and Judaism and their significance for the character of Christianity, London 2006; D.J. Harrington, L'emergere graduale della Chiesa e la "separazione ('the parting of the ways') tra ebraismo e cristianesimo", w: Gesù Cristo e il popolo ebraico: Inerrogativi per la teologia di oggi, red. P.A. Cunningham, J. Sievers, M.C. Boys, H.H. Henrix, J. Svartvik, Roma 2012, s. 149-150; M. Rosik, Church and Synagogue (30-313 AD). Parting of the Ways, Berlin-Bern-Bruxelles-New York-Oxford-Warszawa-Wien 2019.

3 D. Flusser, J. Pelikan, J. Lang, Mary: Images of the Mother of Jesus in Jewish and Christian Perspective, Philadelphia 1986; B. Gaventa, Mary: Glimpses of the Mother of Jesus, Minneapolis 1999; W. Chrostowski, Żydzi i religia żydowska a Maryja Matka Jezusa, „Salvatoris Mater” 2 (2000), nr 1, s. 215-233; S. Hahn, Hail, Holy Queen: The Mother of God in the Word of God, New York 2001; G. Anderson, Mary in the Old Testament, „Pro Ecclesia” 16 (2007), s. 33-55; P. Ladouceur, Old Testament Prefigurations of the Mother of God, „St. Vladimir's Theological Quarterly" 50 (2006), s. 5-57; B. Pitre, Jesus and the Jewish Roots of Mary. Unveiling the Mother of the Messiah, New York 2018. 
Nie ulega wątpliwości, że w środowisku religijnym Palestyny w I wieku status kobiety był nie tylko inny, ale wręcz niższy niż status mężczyzny ${ }^{4}$. Na kobietę spadał ciężar większości domowych obowiązków: pilnowanie trzody, uprawa pola, wypiekanie chleba itp. W sprawach publicznych kobiety zabierały głos tylko w wyjątkowych okolicznościach i doświadczały niższości już od chwili narodzin. O ile narodzinom chłopca towarzyszyła radość, o tyle nie zawsze tak było przy narodzinach dziewczynki. Niezamężna córka należała do ojca i była niekiedy traktowana jak jego własność. Nawet w Dekalogu wymienia się żonę obok innych przedmiotów czy zwierząt (Wj 20,17; Pwt 5,21). Kobieta zresztą nazywała swego męża „właścicielem” lub „panem”.

$\mathrm{Na}$ czym polegał w praktyce ten niższy status kobiet? Jak na tle zwyczajów religijnych i społecznych, które dotyczyły kobiet, widzieć należy postać Maryi? Jak przedstawiają Ją ewangeliści? Szukając odpowiedzi na te pytania, spojrzymy najpierw na sytuację religijną kobiet w Palestynie w I wieku, a następnie na ich życie małżeńskie i rodzinne. W sytuacji Maryi ważne będzie wyjaśnienie kwestii poczęcia Jezusa jeszcze przed Jej przeprowadzeniem się do domu Józefa. A ponieważ ewangeliści kreślą postać Matki Chrystusa, ukazując Jej wyjątkową rolę w historii zbawienia, w ostatniej części artykułu spojrzymy na Nią przez pryzmat życia kobiet, którym Bóg również wyznaczył niebagatelne zadania w dziejach narodu wybranego.

4 „Żaden tekst biblijny odnoszący się do kobiet nie zawiera jakichkolwiek wzmianek o ich niższości duchowej, moralnej czy intelektualnej. Jednak w środowisku Starego Testamentu uważano to za fakt oczywisty i sam przez się zrozumiały. Starożytne Izraelitki żyły w społeczności patriarchalnej, gdzie władza dorosłych i wolnych mężczyzn była szczególnie wielka zarówno prawnie, jak i faktycznie" (M. Bednarz, Biblia na cenzurowanym, Szczecinek 2006, s. 304). 


\section{Maryja - wyznawczyni judaizmu biblijnego}

Najważniejszą instytucją religijną biblijnego Izraela była świątynia jerozolimska. Ewangeliści wyraźnie wzmiankują pobyt Maryi w świątyni przy okazji ofiarowania Jezusa (Łk 2,22-38) i odnalezienia Go pośród nauczycieli Izraela dwanaście lat później (Łk 2,41-50). Przypuścić jednak należy, że bywała tam częściej. Choćby przy okazji święta Paschy, gdy Jezus umierał na krzyżu, czy pięćdziesiąt dni później, po tym jak trwała z uczniami jednomyślnie na modlitwie w Wieczerniku.

Niższy status kobiet w życiu religijnym w stosunku do mężczyzn uwidoczniony został w architekturze świątyni jerozolimskiej; kobietom przeznaczono dla nich wybudowany dziedziniec, którego granic nie powinny przekraczać. $c^{5}$ Oczywiste jest, że w okresie przewidzianym prawem, związanym z nieczystością rytualną wynikającą z krwawienia miesięcznego, kobiety nie miały dostępu nawet do dziedzińca kobiet. Ich udział w kulcie regulowały także inne prawa. Nieczystość kobiety po narodzinach dziecka zależała od płci niemowlęcia. Po narodzinach chłopca matka nie mogła zbliżać się do świątyni ani dotykać przedmiotów kultu przez czterdzieści dni, po narodzinach dziewczynki przez osiemdziesiąt dni. Odpowiedni przepis głosił: „Jeśli kobieta zaszła w ciążę i urodziła chłopca, pozostanie przez siedem dni nieczysta [...]. Potem ona pozostanie przez trzydzieści trzy dni dla oczyszczenia krwi: nie będzie dotykać niczego świętego i nie będzie wchodzić do świątyni, dopóki nie skończą się dni jej oczyszczenia" (Kpł 12,2-4)6. Żydowski kodeks Szulchan Aruch precyzuje: „Winna ona [kobieta] zanurzyć całe swoje ciało, razem z włosami, jednocześnie. Dlatego musi szczególnie dbać o to, aby w chwili zanurzenia nie miała na sobie nic, co by

5 M. Rosik, Judaizm u poczq̨tków ery chrześcijańskiej, Wrocław 2008, s. 38-40.

6 Tenże, Kobieta $w$ życiu religijnym dawnej Palestyny, w: Kobiety $w$ czasach biblijnych, red. I. Skupińska-Lovset, P. Michałowska, Łodź 2008, s. $71-78$. 
oddzielało jej ciało od wody; jeśli bowiem zdarzy się, że jakaś rzecz, choćby najmniejsza, spowoduje oddzielenie, tewila jest nieważna".

Bez wątpienia Maryja brała także udział w nabożeństwach synagogalnych, choćby w rodzinnym Nazarecie. Zapewne bolało Ją bardzo niezrozumienie Jezusa, kiedy po jednym z wystąpień w rodzinnym mieście „wszyscy w synagodze unieśli się gniewem. Porwali Go z miejsca, wyrzucili Go z miasta i wyprowadzili aż na stok góry, na której ich miasto było zbudowane, aby Go strącić" (Łk 4,29).

W synagogach kobiety miały swoje miejsce, oddzielone od mężczyzn (Pwt 31,12). Talmud głosi: „Niewiasty są zwolnione $\mathrm{z}$ nakazów podanych $\mathrm{w}$ formie «musisz, powinieneś» oraz ze wszystkich, które należy wykonać w określonym czasie" (Kiduszin 1,7). Nie musiały odmawiać codziennych modlitw, nie mogły studiować Prawa Mojżeszowego. Nie miały obowiązku brać udziału w świętach pielgrzymich (Pascha, Pięćdziesiątnica, Święto Namiotów). W ostatnie $\mathrm{z}$ wymienionych świąt nie musiały mieszkać $\mathrm{w}$ namiotach. W naukach rabinów pojawia się częściowe uzasadnienie zwolnienia z niektórych obowiązków religijnych: ze względu na dużą ilość prac domowych kobiety nie musiały wypełniać wszystkich zobowiązań natury religijnej ${ }^{7}$. Niektórzy rabini uważali jednak, że mężczyzna i kobieta powinni na równi wykonywać obowiązki religijne ${ }^{8}$.

\section{Maryja w żydowskim małżeństwie}

Małżeństwo w Izraelu było nie tylko komórką społeczną, ale również wspólnotą religijną. Za wiek odpowiedni do małżeń-

7 A. Cohen, Talmud. Syntetyczny wykład na temat Talmudu i nauk rabinów dotyczacych religii, etyki i prawodawstwa, tłum. R. Gromadka, Warszawa 1997, s. 172.

8 H. Daniel-Rops, Żydzi w Palestynie w czasach Chrystusa, tłum. J. Lasocka, Warszawa 2001, s. 118. 
stwa uznawano osiemnaście lat dla mężczyzn, dwanaście lub trzynaście dla palestyńskich kobiet ${ }^{9}$. Inicjatywę w wyborze żony przejmował najczęściej ojciec mężczyzny przygotowującego się do ożenku. Jedynie wtedy, gdy nie było to możliwe, czyniła to matka $^{10}$. Duży udział ojca w wyborze męża dla swej córki tak bardzo nie dziwi, gdy weźmie się pod uwagę młody wiek mężczyzny oraz dziewczyny, która wychodząc za mąż, była praktycznie jeszcze dzieckiem. Narzeczony składał ojcu przyszłej małżonki dar, zwany mocharem, którego wysokość ustalano najczęściej na pięćdziesiąt syklów srebra, a ustaloną sumę zapisywano w tekście sporządzanego dokumentu ${ }^{11}$. Oprócz mocharu przyszły mąż

9 Choć początkowo w Izraelu formalnie małżeństwa z cudzoziemkami nie były zakazane prawem (syn Abrahama urodził się z Egipcjanki, a Mojżesz miał żonę Kuszetkę), to jednak większość Żydów wzdragała się na myśl, że można by mieć za żonę pogankę. Z czasem zabroniono małżeństw z „kobietami przeklętymi”, do których zaliczono Ammonitki i Moabitki. Po powrocie z niewoli babilońskiej (586-538 przed Chr.) Ezdrasz i Nehemiasz zabronili wchodzić w mieszane związki małżeńskie (Ezd 9,12). Co więcej, to właśnie stało się przyczyną poróżnienia się z Samarytanami. Małżeństwa te prowadziły bowiem - zdaniem proroków - do utraty świadomości narodowej. Autor apokryficznej Księgi Jubileuszów zanotował: „Jeśli znajdzie się jakiś człowiek w Izraelu, który chce wydać swą córkę lub swą siostrę za mąż za mężczyznę, który pochodzi z pogan, będzie on musiał zginąć. Niech zostanie ukamienowany, ponieważ sprowadza wstyd na Izrael. Także kobieta będzie spalona w ogniu, gdyż znieważyła imię domu swego ojca" (Księga Jubileuszów 30,7).

$10 \mathrm{Rdz} 21,21$. Gdyby syn ożenił się wbrew woli ojca, małżeństwo takie było ważne, aczkolwiek ojciec mógł pozbawić syna swego błogosławieństwa.

11 Podobne zwyczaje znane były na całym niemal starożytnym Bliskim Wschodzie. Prawo babilońskie nakazywało płacenie tirhatu, którego suma wahała się od jednego do pięćdziesięciu syklów srebra. Tirhatu wypłacano ojcu narzeczonej bądź samej dziewczynie. Nie był to jednak konieczny warunek małżeństwa. Według prawa asyryjskiego tirhatu należało wręczyć bezpośrednio przyszłej małżonce. Według jednej teorii była to rekompensata za utratę dziewictwa, według innej opinii pieniądze miały stanowić finansowe oparcie na wypadek, gdyby małżonka owdowiała. W Babilonii i Asyrii młoda otrzymywała również pewien 
zobowiązany był do mattanu, daru wręczanego przyszłej żonie, który często zatrzymywała dla siebie na wypadek wdowieństwa. Nie jest pewne, czy wszystkich tych przepisów przestrzegano ściśle za czasów Chrystusa, z pewnością jednak je znano i duża część społeczeństwa stosowała się do nich.

Oczywiście z Ewangelii nie wiemy, jak to wyglądało w przypadku Maryi. Ewangeliści nie wspominają o mocharze czy osobistym darze Józefa dla Maryi, nie mówią nic o roli rodziców w zawarciu ich małżeństwa, bo nie to było zasadniczym przedmiotem zainteresowania autorów natchnionych. Ponieważ jednak Mateusz nazywa Józefa „sprawiedliwym”, co oznaczało wierne przestrzeganie Prawa, można przypuścić, że zastosowano wszystkie zwyczaje związane z zawarciem małżeństwa ${ }^{12}$.

Małżeństwo zawierano w dwóch etapach. Pierwszy łączył się z oficjalnym sporządzeniem dokumentu zawarcia małżeństwa. Odbywał się zazwyczaj w gronie najbliższej rodziny. Po sporzą-

posag od ojca, który stanowił jej całkowitą własność. Na wypadek rozwodu lub śmierci współmałżonka cała suma stanowiła własność kobiety; zob. R. de Vaux, Instytucje Starego Testamentu, I-II, tłum. T. Brzegowy, Poznań 2004, s. 27-28.

12 Omijamy tu szerokie omówienie kwestii małżeństwa lewirackiego, gdyż nie dotyczyło ono Maryi. Wspomnijmy tylko, że gdy umierał Żyd, nie pozostawiając po sobie potomstwa, jego brata obowiązywało prawo polegające na poślubieniu żony zmarłego, by wzbudzić potomstwo uważane za potomstwo zmarłego ( $\mathrm{Rdz} 38,6$ i Rt 1,11). Celem małżeństwa lewirackiego było także utrzymanie dziedzictwa w tym samym pokoleniu. Brat zmarłego mógł się jednak wymówić od tego obowiązku. Prawo nakazywało, aby decyzja ta oznajmiona była przez kobietę starszym w bramie miasta. Następnie wdowa miała zdjąć sandał z nogi brata męża i splunąć mu w twarz (Pwt 25,9). Instytucja lewiratu znana była Asyryjczykom (nawet jeśli w okresie narzeczeństwa mężczyzna umierał, jego brat brał narzeczoną za żonę), Hetytom i Hurytom; zob. S. Szymik, Małżeństwo i rodzina w Biblii, w: Życie społeczne w Biblii, red. G. Witaszek, Lublin 1998, s. 222. Wdowa, która zlekceważyła prawo lewiratu i oddała się innemu niż brat zmarłego męża mężczyźnie, uchodziła za winną cudzołóstwa; zob. tamże, s. 218-219. 
dzeniu dokumentu młodzi byli już małżonkami, nie narzeczonymi. Wracali do swych domów i przez mniej więcej rok mieszkali osobno, przygotowując wesele. Po roku następował drugi, o wiele bardziej uroczysty etap - sprowadzenie młodej do domu męża i związane $z$ tym wesele. To właśnie o tym etapie opowiada przypowieść o pannach mądrych i nieroztropnych (Mt 25,1-13). Pan młody wraz z towarzyszami udaje się do domu panny młodej, naprzeciw orszakowi wychodzą przyjaciółki młodej żony, a po spotkaniu wspólnie udają się do jej domu, by w radosnej procesji odprowadzić ją do domu młodego. Wtedy rozpoczyna się wesele. W czasach Jezusa trwało tydzień. W wypadku wdów ograniczano się do trzech dni.

Ewangeliści nie wspominają o weselu Maryi i Józefa, jednak nie ma podstaw przypuszczać, że odbywało się ono wbrew zwyczajom. Łatwiej wyobrazić sobie zamążpójście Maryi tym, którzy odwiedzili Nazaret i wiedzą, że Jej dom od domu Józefa dzieli około dwustu metrów (jeśli oczywiście lokalizacja jest prawidłowa). Trudnością, przed którą stanęli małżonkowie, był natomiast brzemienny stan Maryi, który stał się faktem po pierwszym etapie zaślubin, ale jeszcze przed weselem. Jak widziano to w świetle żydowskiego Prawa?

\section{Prawo rozwodowe i podejrzenia o cudzołóstwo}

Opis narodzenia Jezusa i wydarzeń mu towarzyszących rozpoczyna Mateusz stwierdzeniem: „Po zaślubinach Matki Jego, Maryi, z Józefem, wpierw, zanim zamieszkali razem, znalazła się brzemienną za sprawą Ducha Świętego" (Mt 1,18b). W prawniczej tradycji Starego Testamentu znajduje się zapis: „Kto żonę poślubił, a jeszcze nie sprowadził jej do domu" (Pwt 20,7). Właśnie w tym okresie, po zaręczynach, ale jeszcze przed ceremonią ślubną, podczas której odbywało się przyprowadzenie kobiety do domu męża (Rdz 24,67; Pnp 8,2), zamieszcza Mateusz infor- 
mację o poczęciu Jezusa. Czy są jakieś regulacje prawne, które dotyczą takiej sytuacji? Egzegeci są w tej sprawie podzieleni zasadniczo na dwa obozy: jedni twierdzą, że dziecko poczęte w tym okresie jest z prawowitego łoża, inni sądzą, że jest to dziecko poczęte w cudzołóstwie albo przynajmniej owiane otoczką obyczajowego skandalu.

Pomijając całą długą dyskusję na ten temat, w której bierze się pod uwagę dane Biblii hebrajskiej (Pwt 22,22-27), zapiski Józefa Flawiusza (Antiquitates judaicae VIII,8; IX,5) i Filona z Aleksandrii (De virtutibus XXII), a także dane z Talmudu babilońskiego (Ketubot 1,5; 9b-12a), dojść można do wniosku, który formułuje Raymond E. Brown: w Galilei uważano za obyczajowy skandal poczęcie dziecka po pierwszym, ale przed drugim etapem zaślubin, natomiast w Judei uważano taką sytuację za niemal zwyczajną ${ }^{13}$.

Załóżmy sytuację hipotetyczną, ale bardzo przypominającą sytuację Józefa i Maryi. Małżonkowie są po pierwszym etapie zaślubin, jeszcze przed weselem, i właśnie wtedy poczyna się ich dziecko. Czy jeśli świadkiem ich współżycia było przynajmniej dwóch mężczyzn (o tym szerzej poniżej), należy ich ukamienować? Są już przecież małżeństwem. Albo jeśli jako małżonkowie przed weselem (przeprowadzką młodej do domu męża) spodziewają się narodzin swojego dziecka, czy mężczyzna powinien wręczyć własnej żonie list rozwodowy tylko z tego powodu, że nosi pod sercem jego dziecko? Nikt racjonalnie myślący nie odpowie pozytywnie na żadne z tych dwóch pytań. W końcu mamy

13 R.E. Brown, The Birth of the Messiah. A Commentary on the Infancy Narratives in the Gospel of Matthew and Luke, New York-London-Toronto-Sydney-Auckland 1993, s. 123-125. Niektórzy badacze sugerują, że gdy Józef dowiedział się o brzemiennym stanie Maryi, przygotował wesele (może szybciej niż po roku od sporządzenia dokumentu ślubu), a po nim - zanim jeszcze ciąża Maryi była widoczna - udał się z Nią do Judei, wykorzystując konieczność wzięcia udziału w spisie ludności. Tam ciąża Maryi nikogo nie dziwiła, nawet jeśli poród nastąpił niedługo po Jej przeprowadzeniu do domu Józefa. 
do czynienia z małżonkami. Cała sprawa może wydawać się co najwyżej skandalem obyczajowym. Sąsiedzi mogą patrzeć nieprzychylnie na takich małżonków, jednak wszyscy wiedzą, że niebawem zamieszkają razem i pod jednym dachem wychowają swoje dziecko. Nawoływanie do ukamienowania w pierwszym przypadku lub rozwodu w drugim byłoby czymś nieludzkim. A taka właśnie była sytuacja Józefa i Maryi. Sąsiedzi, którzy sądzili, że fizycznym ojcem dziecka jest Józef, mogli nieprzychylnym okiem patrzeć na małżonków, jednak z pewnością nie wzywali do zabicia Maryi ani nawet do rozwodu. W końcu - jak sądzili mieszkańcy Nazaretu - Maryja z Józefem oczekiwali swego własnego dziecka!

Jednak w starożytnym Izraelu nawet podejrzenie o cudzołóstwo było wystarczającym powodem do rozwodu. Nic więc dziwnego, że Józef zamierzał oddalić swą żonę (o tym poniżej). Jakie były inne motywy, które usprawiedliwiałyby rozwód? W judaizmie biblijnym rozwód był dopuszczalny, a niekiedy wręcz wskazany. Mąż miał prawo oddalić swoją żonę, wręczając jej list rozwodowy. W jakich okolicznościach?

Kobieta podlegała karze za jakąkolwiek formę cudzołóstwa. Z mężczyznami było inaczej: karano ich tylko wtedy, jeśli grzechu dopuścili się z kobietą zamężną. Jeśli zaś mężczyzna cudzołożył z kobietą niezaręczoną, czyn ten uważano za grzeszny, ale karano go jedynie grzywną; mężczyzna musiał wówczas poślubić taką kobietę. W wypadku, w którym trudno było stwierdzić cudzołóstwo kobiety, poddawano ją tak zwanej próbie gorzkich ziół ${ }^{14}$. Już samo podejrzenie kobiety o cudzołóstwo było

14 Próba ta stanowiła rodzaj sądu Bożego, kobieta podejrzana o cudzołóstwo musiała wypić wodę zmieszaną z kurzem zebranym $\mathrm{z}$ posadzki świątynnej. Jeśli praktyce tej nie towarzyszyły żadne dolegliwości zdrowotne, kobieta składała przysięgę swej niewinności oraz „ofiarę posądzenia”, odwołując się do Boga jako Obrońcy. W przeciwnym wypadku uważano ją za winną (Lb 5,18). Próbę gorzkich ziół zwano sota; zob. M. Friedman, Tradycja rodzinna w judaizmie, CT 66 (1996) 2, s. 44. 
wystarczającym powodem do rozwodu. Jeśli rozwód nastąpił, a podejrzenie okazało się niesłuszne, mężczyzna nie miał prawa poślubić jej powtórnie. Jeśli natomiast podejrzenie okazało się prawdziwe, starsi synagogi często domagali się, by mężczyzna wziął rozwód nawet wtedy, gdy był on gotów zatrzymać swą żonę. Rozwód wymagany był również wtedy, gdy kobieta zaszła w ciążę z innym niż jej mąż mężczyzną ${ }^{15}$.

Praktyka rozwodów bazowała na przepisie prawnym: „Jeśli mężczyzna poślubi kobietę i zostanie jej mężem, lecz nie będzie jej darzył życzliwością, gdyż znalazł u niej coś odrażającego, napisze jej list rozwodowy, wręczy go jej, potem odeśle ją od siebie" (Pwt 24,1) ${ }^{16}$. Trzeba zauważyć, że tekst ten jest

15 G. Foot Moore, Judaism in the First Centuries of the Christian Era. The Age of the Tannaim, II, New York 1974, s. 125.

16 Rabinistyczne szkoły różnie interpretowały wspomniany fragment Księgi Powtórzonego Prawa, zastanawiając się nad interpretacją słów „coś odrażającego” (Pwt 24,1). Szkoła rabbiego Hillela zezwalała na rozwód w razie cudzołóstwa żony, a nawet z dużo bardziej błahych powodów, np. takich jak ogólne zaniedbanie obowiązków przez żonę, niewłaściwe zachowanie, złe przygotowanie posiłków; zob. G. Foot Moore, Judaism in the First Centuries of the Christian Era, s. 124. Szamaj nauczał, że wystarczającym powodem rozwodu jest ogólnie rozumiana niemoralność żony. Najbardziej liberalne poglądy w kwestii rozwodu prezentowała szkoła rabbiego Akiby, według którego powodem rozwodu może być każda przyczyna, którą mąż uzna za wystarczającą. Ponieważ za pierwszy i główny cel małżeństwa uważano posiadanie dzieci, a przede wszystkim synów, dlatego wielu spośród rabinów głosiło wręcz powinność napisania listu rozwodowego żonie w razie braku potomstwa po dziesięciu latach pożycia; zob. M. Rosik, Ku radykalizmowi ewangelii. Studium nad wspólnymi logiami Jezusa w Ewangeliach według św. Mateusza i św. Marka, Wrocław 2000, s. 87. Jeśli małżeństwo zawarte zostało z kobietą o pogańskim rodowodzie, każdy powód był wystarczający do rozwodu; zob. H.L. Strack, P. Billerbeck, Das Evangelium nach Markus, Lukas und Johannes und die Apostelgeschichte erläutet aus Talmud und Midrasch, Kommentar zum Neuen Testament aus Talmud und Midrasch, II, München $1989^{9}$, s. 24. A. Di Nola w następujący sposób określa podstawę rozwodu: „Il matrimonio giudaico può essere sciolto attracerso il 
odzwierciedleniem historycznej sytuacji Izraela na sześć wieków przed Chrystusem ${ }^{17}$. Jednak również w czasach Jezusa praktyka rozwodów miała swą podstawę: „Jeśli ktoś z jakiejkolwiek przyczyny chce rozwieść się z żoną - a wśród ludzi często zdarzają się takie wypadki - musi zaświadczyć na piśmie, iż nie będzie już z nią obcował; tylko bowiem po takim oświadczeniu kobieta będzie uprawniona do związania się z innym mężczyzną. Gdyby jednak również drugi mąż źle się z nią obchodził albo gdyby po jego śmierci dawny mąż chciał ją znowu zaślubić, nie będzie już jej wolno wrócić" (Józef Flawiusz, Antiquitates judaicae 4,153) ${ }^{18}$. Wraz z listem rozwodowym kobieta winna otrzymać ketubę, formę odszkodowania, której wysokość zależała od posagu, jaki żona otrzymała, oraz od materialnej sytuacji obojga małżonków. Po oficjalnym wręczeniu listu Prawo nie zezwalało na powtórne połączenie się małżonków.

List rozwodowy niekiedy okazywał się pewną formą ochrony kobiety; znowu stawała się wolna, nie była zniesławiona, i mogła wejść w powtórny związek małżeński ${ }^{19}$. List rozwodowy miał za-

ripudio (mi'un) che è diritto istituzionalmente esercitato dal solo marito e che, in linea di principio, dovrebbe essere applicato quando viene meno l'amore reciproco fondamento dell'unione coniugale" (Ebraismo e giudaismo, Roma 1996, s. 280).

17 Starożytne prawo babilońskie zezwalało mężczyźnie na oddalenie żony po proklamacji słownej formuły rozwodu. Kodeks Hammurabiego przewidywał określoną sumę pieniędzy dla oddalonej żony; jej wysokość zależała od okoliczności rozwodu. Żona mogła wystąpić o rozwód tylko w wypadku oficjalnego (przez sąd) stwierdzenia winy męża. W prawie asyryjskim mąż mógł oddalić swą żonę bez żadnej rekompensaty, ta zaś nigdy nie mogła wystąpić o rozwód; zob. R. de Vaux, Instytucje Starego Testamentu, s. 35-36.

18 Flawiuszowa interpretacja „czegoś odrażającego” (Pwt 24,1) wydaje się dość liberalna, skoro sam rozwiódł się z żoną, gdyż nie podobał mu się „sposób jej postępowania” (Vita 426).

19 „Kobieta żydowska jest chroniona przez list rozwodowy, podobnie jak w małżeństwie jej prawa były zagwarantowane przez kontrakt małżeński zwany ketuwa. Według rabinów winna ona ponownie wyjść za mąż, 
zwyczaj formę niezwykle zwięzłą, często ze ściśle określoną formułą, w której mąż deklarował zerwanie więzów małżeńskich: „Oto jesteś wolna dla każdego mężczyzny” lub „To jest dla ciebie dokument rozwodowy ode mnie, akt zwolnienia i dokument separacji, abyś mogła poślubić jakiegokolwiek mężczyznę, którego zechcesz poślubić" ${ }^{20}$.

Wróćmy do sytuacji Maryi. Co ze wspomnianą karą ukamienowania, w literaturze chrześcijańskiej niemal powszechnie uznawaną za możliwą? W powszechnym przekonaniu wyjawienie prawdy mieszkańcom Nazaretu, że Jezus nie jest dzieckiem Józefa, naraziłoby Maryję na tę właśnie karę śmierci. Odpowiedni przepis prawny głosi: „Ktokolwiek cudzołoży z żoną bliźniego, będzie ukarany śmiercią i cudzołożnik, i cudzołożnica" (Kpł 20,10). Jednak karę ukamienowania można było zastosować tylko wtedy, gdy pojawiło się dwóch mężczyzn - naocznych świadków grzesznego czynu. Świadectwo kobiet nie było brane pod uwagę.

Przypomnijmy scenę zapisaną przez proroka Daniela, kiedy to dwóch mężczyzn fałszywie oskarżyło Zuzannę o grzech cudzołóstwa. Ich świadectwa nie były zgodne, Zuzanna została więc uwolniona, a oni sami musieli ponieść srogą karę.

Czy Jan Chrzciciel wzywał do ukamienowania Herodiady? Nie, bo nikt nie był naocznym świadkiem jej grzesznego pożycia z królem, choć cała sprawa wydawała się oczywista. Czy Samarytance, która przypuszczalnie z powodu niewierności małżeńskiej aż pięciokrotnie otrzymywała listy rozwodowe, groziła śmierć przez ukamienowanie? Ewangelia o tym nie wspomina, bo nie było naocznych świadków grzesznych czynów kobiety.

możliwie najprędzej po upływie 91 dni dozwalających stwierdzić, że nie była w ciąży z pierwszym mężem. Prawo pragnie szczęścia dla kobiety, która została oddalona" (Brat Efraim, Jezus Żyd praktykujący, tłum. J. Fenrychowa, Kraków 1994 , s. 279).

20 M. Hadas-Lebel, Hillel. Maestro della Legge al tempo di Gesù, Casale Monferrato 2002, s. 195. 
A czy przyprowadzonej do Jezusa cudzołożnicy groziła śmierć? Tak, a to dlatego, że przeciwnicy Jezusa wyraźnie ją śledzili, aby przyłapać na cudzołóstwie.

Oczywiste jest, że w przypadku Maryi nikt z ludzi nie był świadkiem Jej grzechu, gdyż takiego nie popełniła. Poczęła Jezusa dzięki Duchowi Świętemu. Nie groził Jej więc grad spadających kamieni.

\section{Maryja - żydowska Matka Jezusa}

Zaledwie kilka ewangelijnych perykop ukazuje Maryję jako Matkę Jezusa: przyjęcie Bożej woli w scenie zwiastowania, nawiedzenie Elżbiety, scena narodzin Jezusa i towarzyszące im wydarzenia (pokłon pasterzy, pokłon mędrców, ofiarowanie w świątyni), ucieczka i powrót z Egiptu, odnalezienie Jezusa w świątyni (przypuszczalnie przy okazji Jego bar micwy), wesele w Kanie, chęć ujrzenia Jezusa otoczonego rzeszą słuchaczy i obecność pod krzyżem. Wszystkie te wydarzenia opowiadają osobistą historię Matki Jezusa, jednak znakomicie odzwierciedlają żydowskie prawa i zwyczaje związane z macierzyństwem. Maryja jawi się w nich jako typowa Żydówka przeżywająca swą macierzyńską więź z Synem tak jak inne żydowskie kobiety.

Choć religijne wychowanie dzieci, zwłaszcza synów, należało do ojca rodziny, matka wspomagała go w tym zadaniu. Po narodzinach dziecka zarówno matka, jak i położnica musiały przejść czas rytualnego oczyszczenia przez zanurzenie ${ }^{21}$. Kobiecie, która dokonywała zanurzenia, towarzyszyła zazwyczaj młoda dziew-

${ }^{21}$ Żydowski kodeks Szulchan Aruch precyzuje: „Winna ona [kobieta] zanurzyć całe swoje ciało, razem z włosami, jednocześnie. Dlatego musi szczególnie dbać o to, aby w chwili zanurzenia nie miała na sobie nic, co by oddzielało jej ciało od wody; jeśli bowiem zdarzy się, że jakaś rzecz, choćby najmniejsza, spowoduje oddzielenie, tewila jest nieważna" (cyt. za: Brat Efraim, Jezus Żyd praktykujący, s. 36). 
czyna; nie mogła jednak jej dotykać. Niekiedy przy obrządku obecny był mąż, co miało umacniać zażyłość pomiędzy małżonkami. Po rytualnej kąpieli należało także złożyć ofiarę za oczyszczenie. Najubożsi winni ofiarować parę synogarlic lub gołębi (Kpł 5,7; 12,8). W razie urodzenia dziewczynki okres oczyszczenia wydłużał się dwukrotnie. Szczegółowe przepisy dotyczące ofiar tego rodzaju zostały omówione w części poświęconej kultowi. Nakazy biblijne powtórzone zostały przez autora Księgi Jubileuszów: „Okres nieczystości po urodzeniu chłopca wynosi siedem dni, a po urodzeniu dziewczynki dwa razy po siedem dni" $(3,8)$.

Izraelici żywili głębokie przekonanie, że pierworodny jest szczególną własnością Boga. Opierali je na tekście Księgi Wyjścia: „Poświęćcie mi wszystko pierworodne. U synów Izraela do mnie należeć będą pierwociny łona matczynego, zarówno człowiek, jak zwierzę" (Wj 13,1-2). Pierwowzoru wykupu pierworodnych szukać należy już w ofierze Izaaka. Bóg sam upatrzył sobie jagnię na całopalenie, przez co oszczędził syna Abrahama (Rdz 22,1-19). Nazwa „wykup” zaczerpnięta została z psalmu: „Nikt bowiem sam siebie nie może wykupić, ani nie uiści ceny Bogu za siebie należnej - jego życie jest zbyt kosztowne" (Ps 49,8-9). Idea wykupu pierworodnych nawiązuje do wykupu niewolników i, zgodnie ze swą etymologią, wskazuje na odkupienie. Pozycja Izraelitów jako narodu wybranego spośród innych nie oznacza, że jest on elitą pośród ludów pogańskich, lecz że przez niego Bóg ma „odkupić” cały rodzaj ludzki²2.

Pierworodnym synom przysługiwały specjalne przywileje: specjalne błogosławieństwo ojca (Rdz 27,30-40), podwójna część dziedzictwa (Pwt 21,17) i przywództwo w rodzie (Rdz 27,28-29). Pierworództwo mogło być utracone, gdy pierworodny syn po-

22 W odniesieniu jednak do samego Izraela Talmud stwierdza: „Biada narodowi, który będzie obecny w godzinie, gdy Święty Błogosławiony zechce zapewnić wykup swoich dzieci! Któż może pragnąć rzucić swoją szatę między lwa i lwicę w chwili, gdy pragną się połączyć" (Sanh. 106,1). 
pełniał ciężkie przestępstwo. W przypadku bliźniąt ten, który pierwszy ujrzał światło dzienne, uważany był za pierworodnego. Podczas gdy pierworodne ze zwierząt oraz pierwociny płodów roli należało złożyć w ofierze, synowie podlegali prawu wykupu. Zasada ta nie dotyczyła jedynie potomków pokolenia Lewiego, gdyż ci przeznaczeni byli do służby świątynnej ${ }^{23}$. Praktyka regulowana była przez konkretny przepis prawny: „I oddasz wszelkie pierwociny łona matki dla Pana i wszelki pierwszy płód bydła, jaki będzie u ciebie; co jest rodzaju męskiego, należy do Pana. Lecz pierworodny płód osła wykupisz jagnięciem, a jeślibyś nie chciał wykupić, to musisz mu złamać kark. Pierworodnych ludzi z synów twych wykupisz" (Wj 13,12-13). Inna regulacja mówi o pięciu syklach srebra (Lb 18,16) ${ }^{24}$.

W procesie wychowania matka wspomagała ojca w nauce modlitw i Prawa. Uczyła dzieci o czystości i nieczystości rytualnej; przekazywała zasady życia moralnego. Ponieważ kobiety nie korzystały z edukacji szkolnej, w przeważającej mierze pozostawały analfabetkami. Nie uczyły więc dzieci sztuki czytania i pisania, lecz zasady religijnego postępowania przekazywały ustnie, a tak-

${ }^{23}$ Paradoksalnie praktykę wykupu pierworodnych potwierdza także historia Samuela, który nie został wykupiony. Właśnie dlatego, że chłopiec od początku swego życia został oddany na służbę w świątyni, ceremonia mogła zostać pominięta. Potwierdzają to słowa matki Samuela: „O tego chłopca się modliłam i spełnił Pan prośbę, którą do Niego zanosiłam. Oto ja oddaję go Panu. Po wszystkie dni, jak długo będzie żył, zostaje oddany na własność Panu" (1 Sm 1,27-28).

24 Praktyka wykupu nie obowiązywała jedynie w przypadku pierworodnych tych małżeństw, w których żony były wdowami mającymi dzieci z poprzedniego związku. M. Friedman podaje także inne przypadki: „[wykup] jest niepotrzebny, gdy któreś z rodziców wywodzi się z rodu kapłanów lub lewitów. Pierworodny musi być pierwszym dzieckiem z łona matki, gdyż jeśli poprzedziły go narodziny siostry, poronienie lub jeśli przyszedł na świat dzięki cesarskiemu cięciu, nie dokonuje się uroczystości wykupu" (M. Friedman, Tradycja rodzinna w judaizmie, s. 44). 
że poprzez przykład codziennego życia, z zachowaniem zwyczajów judaizmu.

\section{Maryja w rzędzie znaczących kobiet Izraela}

W Izraelu czczono kilka kobiet, które uchodziły za narodowe bohaterki. Są wśród nich Sara, Rachela, Miriam, Debora, Judyta, Estera i inne. Czekano także na jeszcze jedną bohaterkę wiary - dziewicę, która będzie Matką Mesjasza. Tak bowiem powszechnie rozumiano w I wieku cytat z Iz 7,14: „Oto Dziewica (hebr. almah) pocznie i porodzi Syna, któremu nadadzą imię Emmanuel". Mateusz jednoznacznie odczytuje te słowa jako potwierdzenie dziewiczego poczęcia, choć almah może oznaczać zarówno dziewicę, jak też niedawno poślubioną młodą matkę. Tłumacz Septuaginty jednak, przekładając tekst hebrajski, zapisał słowo parthenos, które tłumaczyć należy jednoznacznie jako "dziewica”. Stąd też Żydzi oczekiwali, że Matka Mesjasza będzie dziewicą i w kontekście tych oczekiwań należy odczytywać zapis Mateusza. Zapis, któremu ostatecznie sprzeciwili się Żydzi odrzucający mesjańskie posłannictwo Jezusa ${ }^{25}$.

Oprócz bohaterek wiary w historii narodu wybranego ważną rolę odegrały także inne kobiety. Żydzi niekoniecznie stawiali je za wzór do naśladowania, ale ewangelista Mateusz uzasadnia, że odegrały one znaczącą rolę w historii zbawienia. To właśnie o nich wspomina w rodowodzie Jezusa. Są to Tamar, Rachab, Rut i Betszeba.

25 Ponieważ Żydzi, choć sami dokonali takiej interpretacji, nie zgodzili się z nią, gdy chrześcijanie zaczęli głosić, że Maryja była dziewicą, synod faryzeuszów w Jamni zmienił parthenos na neanis (młoda kobieta), zrywając w ten sposób tradycję o dziewiczej matce Emmanuela. Zmiana ta została dokonana za bazie przekładu Akwili, natomiast Septuaginta została odrzucona przez Żydów jako przekład heretycki, akceptowany przez chrześcijan. 
Podać można przynajmniej dwa motywy, które łączą te postacie z osobą Maryi. Po pierwsze, ich związki z partnerami życiowymi są w pewnym sensie nieregularne i choć przez innych postrzegane mogą być jako gorszące, są naznaczone Bożym błogosławieństwem. Po drugie zaś, każda z tych kobiet z własnej woli okazała inicjatywę realizacji Bożego planu i dlatego przez potomnych wspominana była jako narzędzie Bożej opatrzności. Tamar przejęła inicjatywę w jej poniekąd gorszącym związku z Judą. Rachab była nierządnicą, ale to z jej inicjatywy stało się możliwe wejście Izraela do Ziemi Obiecanej. Również związek Moabitki Rut z Boazem miał posmak zgorszenia, niemniej jednak bez inicjatywy Rut dynastia Dawidowa mogłaby w ogóle nie zaistnieć. Salomon mógł zasiąść na tronie dzięki interwencji żony Uriasza, którą wcześniej w podstępny sposób związał ze sobą Dawid. Bóg w historii zbawienia posłużył się tymi kobietami do realizacji swych planów pomimo zgorszenia, jakie stanowiły lub mogły stanowić ich związki z mężczyznami. W tym świetle każe Mateusz spojrzeć swym adresatom na Maryję, której brzemienny stan, zanim jeszcze zamieszkała z Józefem, również mógł być postrzegany jako gorszący, choćby przez samego Józefa.

\section{Maryja - wdowa świadkiem śmierci jedynego Syna?}

Według starożytnej tradycji chrześcijańskiej Maryja stojąca pod krzyżem była już wdową. Scena ta staje się silnym argumentem potwierdzającym fakt, iż Jezus był jedynakiem, czyli argumentem wzmacniającym przekonanie chrześcijan o dziewictwie Maryi także post partum. Dlaczego? Z dwóch powodów.

Po pierwsze dlatego, że potwierdza panujące wśród wielu katolików przekonanie, że bracia i siostry Jezusa, o których mówią Ewangelie, to Jego kuzynostwo. Jan zanotował: „A obok krzy- 
ża Jezusowego stały: Matka Jego i siostra Matki Jego, Maria, żona Kleofasa, i Maria Magdalena" (J 19,25). Jeśli przyjąć - co jest bardzo prawdopodobne i to naprawdę ważki argument - że ewangelista Jan mówi o trzech kobietach o imieniu Maria, które stały pod krzyżem Jezusa, okazuje się, że dwie z nich musiały być kuzynkami. Pierwsza to Maryja, Matka Jezusa. Druga to Maria, siostra Maryi, Matki Jezusa, i jednocześnie żona Kleofasa. Trzecia wreszcie to Maria Magdalena. Matka Jezusa i żona Kleofasa noszą to samo imię (Maria) i są nazwane siostrami. Byłoby bardzo dziwne, gdyby w jednej rodzinie rodzice nazwali dwie swoje córki tym samym imieniem. Najprawdopodobniej chodzi więc o kuzynki ${ }^{26}$.

Po drugie, ta sama scena dostarcza kolejnego argumentu za dziewictwem Maryi: „Kiedy więc Jezus ujrzał Matkę i stojącego obok Niej ucznia, którego miłował, rzekł do Matki: «Niewiasto, oto syn Twój». Następnie rzekł do ucznia: «Oto Matka twoja». I od tej godziny uczeń wziął Ją do siebie" (J 19,25-27). Jan dzieli się osobistymi wspomnieniami. Historyczna interpretacja wskazuje na Jezusową troskę o swoją Matkę. Gdyby Jezus rzeczywiście miał rodzonego brata, w myśl prawa żydowskiego właśnie jemu przypadłby obowiązek zatroszczenia się o Maryję. Fakt, że Jezus powierza Ją Janowi, jest argumentem przeciw tezie o istnieniu braci Jezusa.

\section{Konkluzja}

Lektura ewangelijnych tekstów, w których pojawia się postać Maryi, przez pryzmat społecznych i religijnych zwyczajów i uwarunkowań judaizmu I stulecia w Palestynie prowadzi do dwóch wniosków. Po pierwsze, Matka Chrystusa była typową Żydówką

${ }^{26}$ M. Rosik, Arka i gołębica. Nurt charyzmatyczny w Kościele katolickim, Kraków 2019, s. 415. 
swego czasu, zachowującą obowiązujące zwyczaje i prawa zarówno w życiu religijnym, jak i społecznym i rodzinnym. Po drugie, ewangeliści ukazują Jej absolutnie wyjątkowe znaczenie w dziejach zbawienia, przedstawiając Jej postać na linii starotestamentowych bohaterek, które odegrały ważną rolę w historii narodu wybranego.

\section{The Figure of Mary in the context of the status of Jewish women in Palestine of I century AD}

In recent decades, interest in the Jewish roots of Christianity has been increasing in biblical theology. In the article, the author presents Mary, Mother of Jesus in the context of religious and social life in Palestine of the I century AD. Reading the Gospel texts in this perspective leads to two conclusions. First, the Mother of Christ was a typical Jewish woman of her time, maintaining customs and laws in religious, social and family life. Second, evangelists show her absolutely unique significance in the history of salvation, presenting her character on the line of Old Testament heroines who played an important role in the history of the chosen people. 